\title{
SCIDOC
}

\author{
International Journal of Dentistry and Oral Science (IJDOS) \\ ISSN: 2377-8075
}

\section{Prevalence Of Chronic Periodontitis Among The Adults Aged 20 To 30 Years - An Institutional Based Retrospective Study}

Research Article

Aparna. $\mathrm{M}^{1}$, Balaji Ganesh.S ${ }^{2 *}$, Rakshagan $\mathrm{V}^{3}$

${ }^{1}$ Saveetha Dental College and Hospitals, Saveetha Institute of Medical and technical Sciences, Saveetha University, Chennai, India.

${ }^{2}$ Senior Lecturer, Department of Periodontics, Saveetha Dental College and Hospitals, Saveetha Institute of Medical and technical Sciences, Saveetha University, Chennai, India.

${ }^{3}$ Senior Lecturer, Department of Prosthodontics, Saveetha Dental College and Hospitals, Saveetha Institute of Medical and technical Science, Saveetha University, Chennai, India.

Abstract

Periodontitis is a group of inflammatory diseases affecting the supporting tissues of the tooth. Children and adolescents are subjected to several periodontal diseases. Although there is much lower prevalence of periodontitis in young adults than in older adults. The prevalence of periodontal disease varies in different regions of the world. The aim of this study is to assess the prevalence of periodontitis among young adults. A retrospective study was conducted among a sample of 11,600 adolescents under the age group of 20 to 30 years in the Chennai population who visited Saveetha Dental College for dental check up, among them a total of thousand four hundred and twenty five young patients had periodontitis who were selected for the study. Chronic periodontitis was more common under the age group of 26 to 30 years $(58.6 \%)$ than among the age group of 20 to 25 years $(41.4 \%)$. Males $(64.4 \%)$ were more affected by chronic periodontitis than females $(35.5 \%)$.Localised chronic periodontitis was higher as compared to generalised chronic periodontitis among the age group of 26 to 30 years than patients among the age group of 20 to 25 years. Both localised and generalised chronic periodontitis was seen higher among male patients. The association between age and gender distribution with periodontal diseases was found to be statistically significant.

Keywords: Age; Chronic Periodontitis; Gender; Periodontal Diseases.

\section{Introduction}

Periodontal disease is a chronic inflammatory destruction of tissue surrounding the teeth caused by specific anaerobic pathogens contained in dental plaque organized on the tooth surface. It was believed that accumulation of plaque, poor oral hygiene, occlusal trauma and specific bacterial infections causes periodontal diseases. It has been stated in a study that children and adolescents can have any form of periodontitis [1]. Periodontitis initiates with the inflammation of gingiva and bleeding of gums. Gingiva usually becomes red and swollen, this progression of disease is known as gingivitis which when left untreated may cause and evolve into periodontitis [2]. Periodontitis is a multifactorial disease, with primary aetiological agent being plaque microflora. The etiology is multifactorial with periodontopathogens forming a major crux in the initiation and progression of the disease [3]. As the inflamma- tion progresses deeper, the gingival attachment gets disrupted and a periodontal pocket is formed [4].

Periodontal pocket is an ideal place for harmful bacteria to get colonized and therefore, drives the disease progression more forward. The severity of progression of periodontitis depends upon the balance of number of factors which includes, number and type of bacterial pathogen. Inflammatory mediators and tissue breakdown products have been frequently detected in gingival tissues, gingival crevicular fluid, serum and saliva among the patients with periodontitis [5]. Defense mechanism of an individual depends upon the presence or absence of certain risk factors such as smoking or systemic history such as cardiac disease, diabetes, chronic obstructive pulmonary disorders $[6,7]$.

Environmental, acquired, and genetic risk factors may affect the

\section{*Corresponding Author:}

Balaji Ganesh.S,

Senior Lecturer, Department of Periodontics, Saveetha Dental College and Hospitals, Saveetha Institute of Medical and technical Sciences, Saveetha University, Chennai, India. Tel: 8220713554

E-mail: balajiganeshs.sdc@saveetha.com

Received: May 04, 2021

Accepted: July 09, 2021

Published: July 15, 2021

Citation: Aparna. M, Balaji Ganesh.S, Rakshagan V. Prevalence Of Chronic Periodontitis Among The Adults Aged 20 To 30 Years - An Institutional Based Retrospective Study. Int J Dentistry Oral Sci. 2021;8(7):3168-3173. doi: http://dx.doi.org/10.19070/2377-8075-21000645

Copyright: Balaji Ganesh.S ${ }^{\circ}$ 2021. This is an open-access article distributed under the terms of the Creative Commons Attribution License, which permits unrestricted use, distribution and reproduction in any medium, provided the original author and source are credited. 
onset or progression of periodontitis by modifying the expression of periodontal disease. There are several reports that among the environmental risk factors, tobacco smoking has been found to be associated with an increased prevalence and severity of periodontal disease. Cigarette smoke contains nicotine, cotinine, acrolein, and acetaldehyde, which have detrimental effects on the periodontium. Whereas, smokeless tobacco forms contain areca nut, catechu and lime, which are harmful to the oral structures. Smokeless tobacco use has been associated with several oral manifestations localized at the site of smokeless tobacco placement $[8,9]$.

Bone and tooth loss is commonly seen in an individual with periodontitis and progressive destruction of other supporting structures of the teeth are also identified [10]. Chronic periodontitis based on the extent are classified into two types which includes localised chronic periodontitis in which only $(<30 \%)$ of the sites are affected by periodontitis, whereas in generalised chronic periodontitis $(>30 \%)$ of the sites are affected [11]. Previously our team has a rich experience in working on various research projects across multiple disciplines [12-26]. Therefore, the aim of this study is to evaluate the prevalence of chronic periodontitis among younger adults aged 20 to 30 years.

\section{Materials And Methods}

\section{Study design}

A retrospective study to assess the prevalence rate of chronic periodontitis among the patients aged from 20 to 30 years was conducted in Saveetha Dental College, chennai.Inclusion criteria involved both male and female patients with chronic periodontitis under the age group of 20 to 30 years, smokers, pan chewers. Whereas, exclusion criteria includes patients who had previously undergone periodontal treatment, pregnancy, presence of chronic systemic diseases such as diabetes mellitus, cardiovascular diseases, epileptic patients, hematological disorders.

\section{Ethicals}

Before scheduling of the retrospective study, the official permission was obtained from the Institutional ethical committee (ethical approval number- SDC/ SIHEC/ 2020/ DIASDATA/ 06190320).

\section{Data collection}

Among a sample of 11,600 adolescents under the age group of 20 to 30 years in the Chennai population who visited Saveetha Dental
College for dental check up, a total of thousand four hundred and twenty five young patients who had periodontitis were selected for the study. Case reports of each patient were retrieved from the archives of saveetha dental college. Data collection includes various parameters such as age, gender (male or female), habit history (history of adverse oral habits such as tobacco smoking and pan chewing), and presence or absence of chronic periodontitis and type of periodontal disease. Based on the severity of periodontal disease the patients were categorised into localised chronic periodontitis and generalised chronic periodontitis. These data were retrieved from dental records from June 2019 to March 2020.

\section{Data analysis}

The Data collected was tabulated in excel sheets and were imported to SPSS (version 26.0). Data was analysed using chi-square test and frequency of distribution of the disease which was used to determine the prevalence rates of periodontitis among the selected population. $P$ value less than 0.05 was considered to be statistically significant. Association between between the age groups of the study population and the type of periodontal disease was analysed. Association between the gender of the study population and the type of periodontal disease was also analysed. The results were demonstrated in the form of bar graphs.

\section{Results And Discussion}

Oral diseases have a significant impact on the social and psychological aspects of one individual's life. Exposure to various risk factors like age, poor oral hygiene status, smoking, stress, systemic diseases and genetic factors are associated with an increased risk of periodontitis among adolescents. There are several studies in which researchers have attempted various clinical trials for regenerative methods using PRF, Growth factors and stem cells [27-32], and numerous in-vitro studies for the treatment of periodontitis were evaluated over the past 5 years [33-37]. In this present study, the prevalence of chronic periodontitis among the age group under 20-30 years in the Chennai population was evaluated. Parameters that were assessed in this study include age group (20 -25 and 26 to 30 years). Habit history (pan chewing and smoking status), systemic history, periodontal disease (localised and generalised chronic periodontitis).

Among thousand four hundred and twenty five patients with periodontitis, frequency distribution of age among the patients with chronic periodontitis were assessed in this study (Graph-1) which infers that, patients with chronic periodontitis under the age group of 26 to 30 years $(58.6 \%)$ were more prevalent than among the age group of 20 to 25 years. Similarly Peeran et al had assessed

Graph 1. Bar graph represents frequency distribution of age among the patients with chronic periodontitis. $\mathrm{X}$ axis represents age distribution. $Y$ axis represents the number of patients who have periodontitis. Chronic periodontitis was more common under the age group of 26 to 30 years (yellow) $58.6 \%$ than among the age group of 20 to 25 years (dark blue) $41.40 \%$.

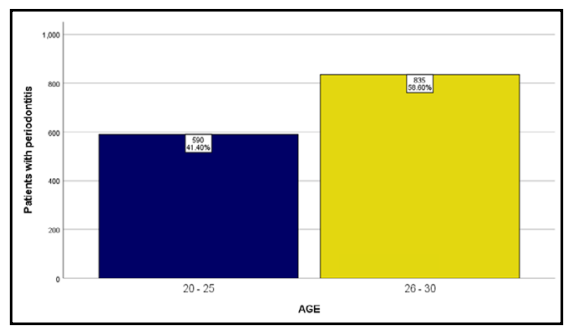


Graph 2. Bar graph represents frequency of distribution of gender among the patients with chronic periodontitis. $\mathrm{X}$ axis represents gender distribution. Y axis represents the number of patients who have periodontitis. Males (light purple) $64.42 \%$ were more affected by chronic periodontitis than females (pink) $35.58 \%$.

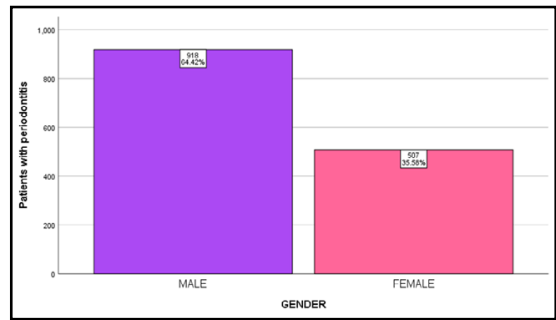

Graph 3. Bar graph represents frequency distribution of smoking history [yes (blue),no(red)] among the patients with chronic periodontitis. $\mathrm{X}$ axis represents smoking history. $\mathrm{Y}$ axis represents the number of patients who have periodontitis. Lesser prevalence of smoking habits $(6.18 \%)$ was seen among the selected population.

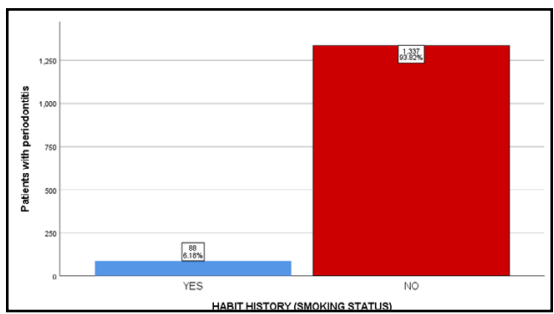

Graph 4. Bar graph represents frequency of distribution of pan chewing history [yes (blue), no (red)] among the patients with chronic periodontitis. $\mathrm{X}$ axis represents pan chewing history. $\mathrm{Y}$ axis represents the number of patients who have periodontitis. Lesser prevalence of pan chewing habit (3.65\%) was seen among the selected population.

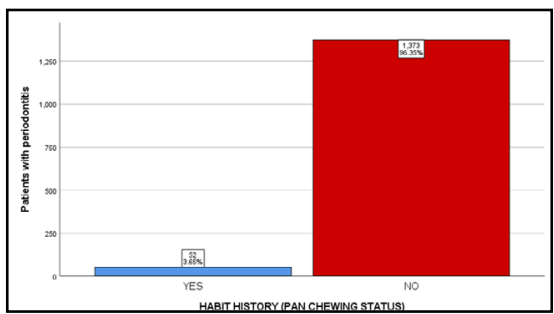

Graph 5. Bar graph represents frequency of distribution of periodontal disease among the selected population. $\mathrm{X}$ axis represents patients with periodontal disease. $Y$ axis represents the number of patients who had localised and generalised chronic periodontitis. Localised chronic periodontitis (orange) $91.16 \%$ was more prevalent than generalised chronic periodontitis (yellow) $8.84 \%$ among the selected participants.

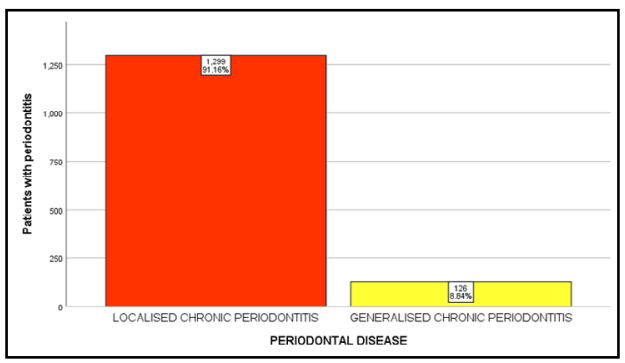

Graph 6. Bar graph represents association between age and patients with chronic periodontitis. $\mathrm{X}$ axis represents age. $\mathrm{Y}$ axis represents patients with localised and generalised chronic periodontitis. Localised chronic periodontitis (orange) was seen higher as compared to generalised chronic periodontitis (yellow) among the age group of 26 to 30 years. Chi square test was done for association and $P$ value $=0.003$ was statistically significant.

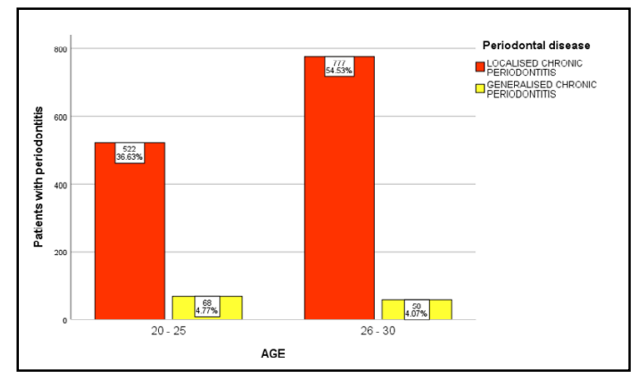


Graph 7. Bar graph showing the association between gender distribution and periodontal disease among the selected participants. $\mathrm{X}$ axis represents the gender distribution of the patients with chronic periodontitis. $Y$ axis represents the number of patients who had localised and generalised chronic periodontitis. Both localised (orange) and generalised chronic periodontitis (yellow) was higher among males as compared to females. Chi square test was done for association and $\mathbf{P}$ value $=$ 0.035 was statistically significant.

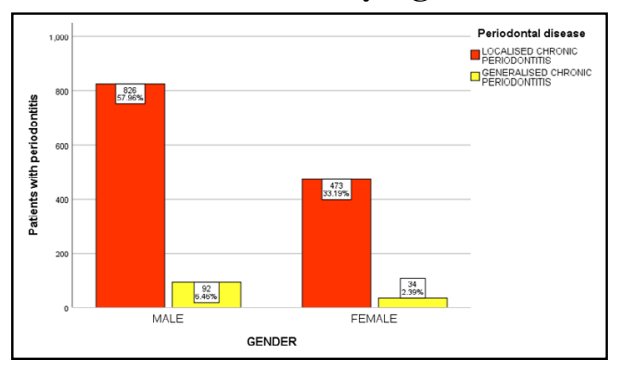

the periodontal status and its risk factors among young adults and stated that among the prevalence of periodontitis among the age group of 24 to 30 years was higher than patients under the age group of 18 to 23 years [38]. In our study, frequency distribution of gender among the patients with chronic periodontitis was assessed (Graph-2) which infers that males (64.42\%) were more prevalently affected by periodontitis than females(35.58\%).Similar to our results, Ioannidou et al stated that periodontitis has a documented higher prevalence in men as compared to women [39].

This study evaluated the frequency distribution of smoking history among the patients with chronic periodontitis (Graph-3) which infers lesser prevalence of smoking history (6.18\%) was seen among the selected population. Similarly Josef et al had assessed the frequency distribution of smoking habits among periodontitis patients and stated that the effect of smoking had a deleterious effect on periodontal status. Smoking affects both gingival epithelium and connective tissue. Smoking is an independent risk factor for the initiation, extent and severity of periodontal diseases [40-42].

In our study, frequency distribution of pan chewing history among the patients with chronic periodontitis was assessed (Graph-4) which infers lesser prevalence of pan chewing status (3.65\%) was seen among the selected population. Similarly Giri et al assessed the frequency distribution of pan chewing habit among periodontitis patients and stated that the pan chewing habit adversely affects the periodontal health of the consumers [43]. Graph - 5 represents the frequency distribution of localised and generalised chronic periodontitis among the selected population which infers that localised chronic periodontitis $(91.16 \%)$ was more prevalent than generalised chronic periodontitis(8.84\%).Similarly, Nabeeh A Qahtani et al had stated that localised chronic periodontitis was more prevalent than generalised chronic periodontitis among young adults [44]. A study conducted in brazil also found that localised chronic periodontitis prevalence was high and its presence was associated with age, socioeconomic status and dental calculus [45].

Association between age group and chronic periodontitis was done in our study, (Graph-6) which infers that 522 patients $(36.63 \%)$ had localised chronic periodontitis and 68 patients $(4.77 \%)$ of them had generalised chronic periodontitis among the age group of 20 to 25 years. Whereas, at the age group of 26 to 30 years, 777 patients $(54.53 \%)$ had localised chronic periodonti- tis and 58 patients $(4.07 \%)$ had generalised chronic periodontitis. Chi square test was done for association and $\mathrm{P}$ value $=0.003$ was statistically significant.Similar to our results demmer et al stated that the prevalence of localised chronic periodontitis among the age group of 18 to 30 years than gener chronic periodontitis [46].

In this study, association of gender and chronic periodontitis was done (Graph -7) in which among males, 826 patients $(57.96 \%)$ had localised and 92 patients $(6.46 \%)$ had generalised chronic periodontitis.Among females, 473 patients (33.19\%) had localised and 34 patients had $(2.39 \%)$ of them had generalised chronic periodontitis. Chi square test was done for association and $\mathrm{P}$ value $=0.035$ was statistically significant.Similarly rao et al stated that males are more prevalently affected by both the diseases than females [47]. Whereas contradictory to our results albander et al reported higher prevalence of periodontitis in females than in males [48]. Limitation of our study in which the sample size is restricted only to an institution among the Chennai population. Therefore larger study samples to be evaluated and the study could have been assessed among different geographic locations for more accuracy.Our institution is passionate about high quality evidence based research and has excelled in various fields [49-59].

\section{Conclusion}

Localised chronic periodontitis was higher as compared to generalised chronic periodontitis among the age group of 26 to 30 years than patients among the age group of 20 to 25 years. Both localised and generalised chronic periodontitis was seen higher among male patients. Oral diseases have been associated with mankind from time immemorial, but as they are rarely life-threatening, their prevention or treatment is often accorded a low priority by health policy makers. However, these oral diseases have a significant impact on both the social and psychological aspects of an individual's life. Oral health problems are highly prevalent in the adolescents. Hence attention should be focused on improving the oral health status of adolescents. Thus, it is important to create more awareness and provide quality dental care for the general welfare of the community.

\section{Acknowledgement}

The authors would like to thank the study participants for their participation and Saveetha Dental College for providing a platform to express our knowledge. 


\section{References}

[1]. Periodontology RSATC of TAA of, Research, Science and Therapy Committee of the American Academy of Periodontology. Position Paper: Periodontal Diseases of Children and Adolescents. J. Periodontol. 2003;74.1696-704.

[2]. Tonetti MS, Mombelli A. Early-onset periodontitis. Ann. Periodontol. 1999 Dec;4(1):39-52.

[3]. Ramesh A, Varghese SS, Doraiswamy JN, Malaiappan S. Herbs as an antioxidant arsenal for periodontal diseases. J Intercult Ethnopharmacol. 2016 Jan 27;5(1):92-6.Pubmed PMID: 27069730.

[4]. Armitage GC. Development of a classification system for periodontal diseases and conditions. Ann. Periodontol. 1999 Dec;4(1):1-6.

[5]. Varghese SS, Thomas H, Jayakumar ND, Sankari M, Lakshmanan R. Estimation of salivary tumor necrosis factor-alpha in chronic and aggressive periodontitis patients. Contemp Clin Dent. 2015 Sep;6(Suppl 1):S152-6. Pubmed PMID: 26604566

[6]. Lenggogeny P, Masulili SL, Tadjoedin FM, Radi B. Levels of interleukin-1 $\beta$ in gingival crevicular fluid in patients with coronary heart disease and its relationship to periodontal status. In AIP Conference Proceedings. $2017 \mathrm{Feb}$ 21;1817(1):030004.

[7]. Ramesh A, Varghese SS, Jayakumar ND, Malaiappan S. Chronic obstructive pulmonary disease and periodontitis-unwinding their linking mechanisms. J. Oral Biosci. 2016 Feb 1;58(1):23-6.

[8]. Mittal S, Dani N, Abullais SS, Al-Qahtani NA, Shah K. Effect of Smoking and Tobacco Chewing on Periodontal Disease and Non-Surgical Treatment Outcome: A Clinical and Biochemical Study. J Int Acad Periodontol.. 2017 Dec 24;20(1):12-8.

[9]. Verma SK, Kumar BD, Singh S, Kumari P, Agarwal A, Singh TK, et al. Effect of gutkha chewing on periodontal health and oral hygiene of peoples in Delhi NCR region of North India: A cross-sectional multicentered study. J Family Med Prim Care. 2019 Feb;8(2):564-567.Pubmed PMID: 30984673.

[10]. Locker D, Slade GD, Murray H. Epidemiology of periodontal disease among older adults: a review. Periodontology 2000. 1998 Feb 1;16:16-33.

[11]. Nanaiah KP, Nagarathna DV, Manjunath N. Prevalence of periodontitis among the adolescents aged 15-18 years in Mangalore City: An epidemiological and microbiological study. J Indian Soc Periodontol. 2013 Nov;17(6):784-9.Pubmed PMID: 24554891.

[12]. Hafeez N. Accessory foramen in the middle cranial fossa. Res J Pharm Technol. 2016;9(11):1880-2.

[13]. Krishnan RP, Ramani P, Sherlin HJ, Sukumaran G, Ramasubramanian A, Jayaraj G, et al. Surgical Specimen Handover from Operation Theater to Laboratory: A Survey. Ann Maxillofac Surg. 2018 Jul-Dec;8(2):234-238. Pubmed PMID: 30693238

[14]. Somasundaram S, Ravi K, Rajapandian K, Gurunathan D. Fluoride Content of Bottled Drinking Water in Chennai, Tamilnadu. J Clin Diagn Res. 2015 Oct;9(10):ZC32-4.Pubmed PMID: 26557612.

[15]. Felicita AS. Orthodontic extrusion of Ellis Class VIII fracture of maxillary lateral incisor - The sling shot method. Saudi Dent J. 2018 Jul;30(3):265269.Pubmed PMID: 29942113.

[16]. Kumar S, Rahman R. Knowledge, awareness, and practices regarding biomedical waste management among undergraduate dental students. Asian J. Pharm. Clin. Res. 2017;10(8):341.

[17]. Gurunathan D, Shanmugaavel AK. Dental neglect among children in Chennai. J Indian Soc Pedod Prev Dent. 2016 Oct 1;34(4):364.

[18]. Sneha S. Knowledge and awareness regarding antibiotic prophylaxis for infective endocarditis among undergraduate dental students. Asian J. Pharm. Clin. Res. 2016 Oct 1:154-9.

[19]. Dhinesh B, Lalvani JI, Parthasarathy M, Annamalai K. An assessment on performance, emission and combustion characteristics of single cylinder diesel engine powered by Cymbopogon flexuosus biofuel. Energy Convers Manage. 2016 Jun 1;117:466-74.

[20]. Choudhari S, Thenmozhi MS. Occurrence and Importance of Posterior Condylar Foramen. Res J Pharm Technol. 2016;9(8):11-43.

[21]. Paramasivam A, Vijayashree Priyadharsini J, Raghunandhakumar S. N6adenosine methylation $(\mathrm{m} 6 \mathrm{~A})$ : a promising new molecular target in hypertension and cardiovascular diseases. Hypertens Res. 2020 Feb;43(2):153154.Pubmed PMID: 31578458

[22]. Wu F, Zhu J, Li G, Wang J, Veeraraghavan VP, Krishna Mohan S, et al. Biologically synthesized green gold nanoparticles from Siberian ginseng induce growth-inhibitory effect on melanoma cells (B16). Artif Cells Nanomed Biotechnol. 2019 Dec;47(1):3297-3305.Pubmed PMID: 31379212.

[23]. Palati S, Ramani P, Shrelin HJ, Sukumaran G, Ramasubramanian A, Don $\mathrm{KR}$, et al. Knowledge, Attitude and practice survey on the perspective of oral lesions and dental health in geriatric patients residing in old age homes. Indian J Dent Res. 2020 Jan-Feb;31(1):22-25.Pubmed PMID: 32246676.

[24]. Saravanan M, Arokiyaraj S, Lakshmi T, Pugazhendhi A. Synthesis of silver nanoparticles from Phenerochaete chrysosporium (MTCC-787) and their antibacterial activity against human pathogenic bacteria. Microb Pathog. 2018 Apr;117:68-72.Pubmed PMID: 29427709.

[25]. Govindaraju L, Gurunathan D. Effectiveness of Chewable Tooth Brush in Children-A Prospective Clinical Study. J Clin Diagn Res. 2017 Mar;11(3):ZC31-ZC34.Pubmed PMID: 28511505.

[26]. Vijayakumar Jain S, Muthusekhar MR, Baig MF, Senthilnathan P, Loganathan S, Abdul Wahab PU, et al. Evaluation of Three-Dimensional Changes in Pharyngeal Airway Following Isolated Lefort One Osteotomy for the Correction of Vertical Maxillary Excess: A Prospective Study. J Maxillofac Oral Surg. 2019 Mar;18(1):139-146.Pubmed PMID: 30728705.

[27]. Avinash K, Malaippan S, Dooraiswamy JN. Methods of Isolation and Characterization of Stem Cells from Different Regions of Oral Cavity Using Markers: A Systematic Review. Int J Stem Cells. 2017 May 30;10(1):12-20. Pubmed PMID: 28531913.

[28]. Panda S, Jayakumar ND, Sankari M, Varghese SS, Kumar DS. Platelet rich fibrin and xenograft in treatment of intrabony defect. Contemp Clin Dent. 2014 Oct; $5(4): 550-4$

[29]. Mootha A, Malaiappan S, Jayakumar ND, Varghese SS, Toby Thomas J. The Effect of Periodontitis on Expression of Interleukin-21: A Systematic Review. Int J Inflam. 2016;2016:1-8.Pubmed PMID: 26998377.

[30]. Ravi S, Malaiappan S, Varghese S, Jayakumar ND, Prakasam G. Additive effect of plasma rich in growth factors with guided tissue regeneration in treatment of intrabony defects in patients with chronic periodontitis: a split-mouth randomized controlled clinical trial. J. Periodontol.. 2017 Sep;88(9):839-45.

[31]. Khalid W, Varghese SS, Sankari M, Jayakumar ND. Comparison of Serum Levels of Endothelin-1 in Chronic Periodontitis Patients Before and After Treatment. J Clin Diagn Res. 2017 Apr;11(4):ZC78-ZC81.Pubmed PMID: 28571268.

[32]. Khalid W, Vargheese SS, Lakshmanan R, Sankari M, Jayakumar ND. Role of endothelin-1 in periodontal diseases: A structured review. Indian J Dent Res. 2016 May-Jun;27(3):323-33.Pubmed PMID: 27411664.

[33]. Kavarthapu A, Thamaraiselvan M. Assessing the variation in course and position of inferior alveolar nerve among south Indian population: A cone beam computed tomographic study. Indian J Dent Res. 2018 JulAug;29(4):405-409.Pubmed PMID: 30127186.

[34]. Ramesh A, Ravi S, Kaarthikeyan G. Comprehensive rehabilitation using dental implants in generalized aggressive periodontitis. J. Indian Soc. Periodontol. $2017 \mathrm{Mar} ; 21(2): 160$.

[35]. Ramesh A, Vellayappan R, Ravi S, Gurumoorthy K. Esthetic lip repositioning: A cosmetic approach for correction of gummy smile - A case series. J Indian Soc Periodontol. 2019 May-Jun;23(3):290-294.Pubmed PMID: 31143013.

[36]. Priyanka S, Kaarthikeyan G, Nadathur JD, Mohanraj A, Kavarthapu A. Detection of cytomegalovirus, Epstein-Barr virus, and Torque Teno virus in subgingival and atheromatous plaques of cardiac patients with chronic periodontitis. J Indian Soc Periodontol. 2017 Nov-Dec;21(6):456-460.Pubmed PMID: 29551863.

[37]. Thamaraiselvan M, Elavarasu S, Thangakumaran S, Gadagi JS, Arthie T. Comparative clinical evaluation of coronally advanced flap with or without platelet rich fibrin membrane in the treatment of isolated gingival recession. J Indian Soc Periodontol. 2015 Jan;19(1):66-71.

[38]. Peeran SW, Singh AJ, Alagamuthu G, Peeran SA, Naveen Kumar PG. Periodontal status and risk factors among adults of Sebha City (Libya). Int. J. Dent.. 2012 Nov 14:2012:1-5.

[39]. Ioannidou E. The Sex and Gender Intersection in Chronic Periodontitis. Front Public Health. 2017 Aug 4;5:189.Pubmed PMID: 28824898.

[40]. Borojevic T. Smoking and periodontal disease. Mater Sociomed. 2012;24(4):274-6

[41]. Hayman L, Steffen MJ, Stevens J, Badger E, Tempro P, Fuller B, et al. Smoking and periodontal disease: discrimination of antibody responses to pathogenic and commensal oral bacteria. Clin Exp Immunol. 2011 Apr;164(1):118-26.Pubmed PMID: 21303363.

[42]. Ramamurthy JA, Mg V. Comparison of effect of Hiora mouthwash versus Chlorhexidine mouthwash in gingivitis patients: A clinical trial. Asian J Pharm Clin Res. 2018 Jul 7;11(7):84-8.

[43]. Giri DK, Kundapur P, Bhat KM, Maharjan IK. Betel Nut Chewing Associated With Severe Periodontitis . Health Renaissance. 2015;12:57-60.

[44]. Al Qahtani NA, Joseph B, Deepthi A, Vijayakumari BK. Prevalence of chronic periodontitis and its risk determinants among female patients in the Aseer Region of KSA. J Taibah Univ Med Sci. 2017 Mar 3;12(3):241-248. Pubmed PMID: 31435246.

[45]. Susin C, Albandar JM. Aggressive periodontitis in an urban population in southern Brazil. J Periodontol. 2005 Mar;76(3):468-75.Pubmed PMID: 15857083.

[46]. Demmer R, Papapanou PN. Epidemiologic patterns of chronic and aggres- 
sive periodontitis. Periodontol 2000. 2010 Jun;53:28-44.

[47]. Balaji SK, Lavu V, Rao S. Chronic periodontitis prevalence and the inflammatory burden in a sample population from South India. Indian J Dent Res. 2018 Mar-Apr;29(2):254-259.Pubmed PMID: 29652025.

[48]. Albandar JM. Periodontal diseases in north america. Periodontol 2000. 2002 Apr;29(1):31-69.

[49]. Vijayashree Priyadharsini J. In silico validation of the non-antibiotic drugs acetaminophen and ibuprofen as antibacterial agents against red complex pathogens. J Periodontol. 2019 Dec;90(12):1441-1448.Pubmed PMID: 31257588

[50]. Pc J, Marimuthu T, Devadoss P, Kumar SM. Prevalence and measurement of anterior loop of the mandibular canal using CBCT: A cross sectional study. Clin Implant Dent Relat Res. 2018 Apr 6;20(4):531-4.

[51]. Ramesh A, Varghese S, Jayakumar ND, Malaiappan S. Comparative estimation of sulfiredoxin levels between chronic periodontitis and healthy patients - A case-control study. J Periodontol. 2018 Oct;89(10):1241-1248.Pubmed PMID: 30044495.

[52]. Ramadurai N, Gurunathan D, Samuel AV, Subramanian E, Rodrigues SJ. Effectiveness of 2\% Articaine as an anesthetic agent in children: randomized controlled trial. Clin Oral Investig. 2019 Sep;23(9):3543-50.

[53]. Sridharan G, Ramani P, Patankar S, Vijayaraghavan R. Evaluation of salivary metabolomics in oral leukoplakia and oral squamous cell carcinoma. J Oral Pathol Med. 2019 Apr;48(4):299-306
[54]. Ezhilarasan D, Apoorva VS, Ashok Vardhan N. Syzygium cumini extract induced reactive oxygen species-mediated apoptosis in human oral squamous carcinoma cells. J Oral Pathol Med. 2019 Feb;48(2):115-121.Pubmed PMID: 30451321.

[55]. Mathew MG, Samuel SR, Soni AJ, Roopa KB. Evaluation of adhesion of Streptococcus mutans, plaque accumulation on zirconia and stainless steel crowns, and surrounding gingival inflammation in primary molars: randomized controlled trial. Clin Oral Investig. 2020 Sep;24(9):1-6.Pubmed PMID: 31955271.

[56]. Samuel SR. Can 5-year-olds sensibly self-report the impact of developmental enamel defects on their quality of life? Int J Paediatr Dent. 2021 Mar;31(2):285-286.Pubmed PMID: 32416620.

[57]. R H, Ramani P, Ramanathan A, R JM, S G, Ramasubramanian A, et al. CYP2 C9 polymorphism among patients with oral squamous cell carcinoma and its role in altering the metabolism of benzo[a]pyrene. Oral Surg Oral Med Oral Pathol Oral Radiol. 2020 Sep;130(3):306-312.Pubmed PMID: 32773350.

[58]. Chandrasekar R, Chandrasekhar S, Sundari KKS, Ravi P. Development and validation of a formula for objective assessment of cervical vertebral bone age. Prog Orthod. 2020 Oct 12;21(1):38.Pubmed PMID: 33043408.

[59]. Priyadharsini JV, Girija AS, Paramasivam A. In silico analysis of virulence genes in an emerging dental pathogen A. baumannii and related species. Arch. Oral Biol. 2018 Oct 1;94:93-8. 